\title{
Kardiovaszkuláris kockázatbesorolás: igen nagy, nagy, közepes, kis kockázat 2017
}

\author{
Pados Gyula', Karádi István², Kiss Róbert Gábor³, Paragh György4, \\ Tóth Kálmán ${ }^{6}$, Bajnok Lászlób, Szollár Lajos ${ }^{5}$
}

\begin{abstract}
${ }^{1}$ Szt. Imre Egyetemi Oktatókórház, Anyagcsere Központ, Budapest; ${ }^{2}$ Semmelweis Egyetem ÁOK, III. sz. Belgyógyászati Klinika, Budapest; ${ }^{3}$ Honvédkórház, Kardiológiai Osztály, Budapest; ' ${ }^{4}$ Debreceni Egyetem Klinikai Központ, I. sz. Belgyógyászati Klinika, Anyagcsere Betegségek Tanszék, Debrecen; ${ }^{5}$ Semmelweis Egyetem ÁOK, Kórélettani Intézet, Budapest; ${ }^{6}$ Pécsi Tudományegyetem, Klinikai Központ, I. sz. Belgyógyászati Klinika, Pécs
\end{abstract}

Levelezési cím:

Dr. Pados Gyula, e-mail: dr.pados@gmail.com

2003, az első Magyar Kardiovaszkuláris Konszenzus Konferencia (MKKK) óta a kardiovaszkuláris (CV) kockázati kategóriákban sorra következtek be változások. Bevezettük az igen nagy kockázati kategóriát, bevontuk ebbe a CV-betegségeket, bizonyos feltételek mellett a diabéteszt és krónikus vesebetegséget (CKD), valamint a Familiáris Hypercholesterinaemia $(\mathrm{FH})$ is ide került.

Jelenleg az igen nagy kockázatba a klinikailag igazolt, vagy dokumentált CV-betegségeket, a súlyos vesebetegséget (GFR $\leq 30 \mathrm{ml} / \mathrm{min} / 1,73 \mathrm{~m}^{2}$ ) proteinuriával kísérve, a diabéteszt legalább 1 major rizikófaktor (RF) és/vagy célszervkárosodás esetén soroltuk be. A Magyar Atherosclerosis (MAT) és Kardiológusok Társasága (MKT) közötti egyeztetés után az FH opcionálisan maradt ebben a kategóriában, amely perszonális megítélésre ad lehetőséget. Lényegesen változtattunk a nagy, közepes és kis kockázatban, rizikófaktorok kiemelt felsorolása helyett a SCORE Chart került előtérbe, amely a 4 fö rizikófaktornak (a dohányzás, hipertónia, hypercholesterinaemia, életkor) jelenléte alapján határozza meg a kategóriákat. Ezzel is ösztönözzük az orvosokat, hogy gyakrabban használják a SCORE-táblázatot. A nagy kockázatba az igen nagy kockázatból kimaradt cukorbetegek és a vesebajok enyhébb formái, valamint a perifériás verőérbetegséget jelző marker kerültek, valamint a $\geq 5$-9\% SCORE-értékủek. Közepes és kis kockázatból - duplikáció elkerülésére - kihagytuk az RF-okat, s csak a SCORE-t tartottuk meg, $>1 \%-<5 \% / 10$ év szinten. Ehhez a konszenzushoz elsősorban a kezdeményező és alapító Magyar Atherosclerosis és a Magyar Kardiológusok társaságának egyetértése kellett, meg a nagy RF-ok képviselőié. Jelen ajánlásunk nagyrészt harmonizál az ESC/EAS 2016-os irányelveivel.

Kulcsszavak: Magyar Kardiovaszkuláris Konszenzus Konferencia 2017, kockázatbesorolás, SCORE kockázatbecslés

Categorisation of Cardiovascular Risks: Very high, High, Moderate, or Low Risk Category - 2017

Since 2003, the First Hungarian Cardiovascular Consensus Conference (MKKK), there have been several changes in the cardiovascular (CV) risk categories. Recently, we have included into the very high risk category the CV diseases which were clinically proven or documented by imaging methods, severe kidney diseases (GFR $\leq 30 \mathrm{ml} / \mathrm{mins}$ ) accompanied by proteinuria, diabetes and/or target organ damage, or cases where at least one major risk factor was present. Based on the agreement between the Association of the Hungarian Cardiologists (MKT) and the Hungarian Association of Atheroclerosis (MAT), familial hypercholesterolemia $(\mathrm{FH})$ remained in this category optionally. In terms of simplification, we have made changes in the high, moderate and low categories: instead of the highlighted listing of the risk factors, the SCORE chart was emphasized, which defines the categorisation according to the presence and degree of the four major risk factors (age, smoking, hypertension and hypercholesterolemia). In this way, we also wish to urge physicians to apply the SCORE chart more often. Into the high risk category diabetes patients omitted from the very high risk category, the relatively less severe forms of kidney diseases were included, as well as one marker of the peripheral atherosclerosis, and also those with the SCORE value of 5-9\%. In the moderate and low category we have only retained the SCORE chart (at the level of $>1 \%-<5 \% / 10$ years, respectively.) To achieve this consensus, first of all, the agreement of the initiating and founding MAT and MKT was needed. Our present recommendation for the risk categorisation largely corresponds with the 2016 guidelines of ESC/EAS.

Keywords: Hungarian Cardiovascular Consensus Conference 2017, categorisation of cardivasculer risks, SCORE chart 


\section{Bevezetés}

Hangsúlyozni kell, hogy a Konszenzus Konferenciák üzenete, javaslata nem csak egy cikkben van összefoglalva, $s$ a teljes ajánlást csak másik 3-4 anyaggal együtt értékelhetjük. Ez különösen vonatkozik a kockázatbesorolásra is. Minden konferencia előtt meghívottak részvételével előkészítő zártkörű kerekasztal konferenciát szervezünk. 2017-ben ez október 24-én történt, ahol 17 orvosi társaság képviselői szólhattak hozzá, tehettek javaslatokat a Kockázati Kategóriák kialakításához is. Nem véletlen, hogy erröl a témáról a Metabolizmus konszenzusi különszámában írt cikkünkben a legtöbb, 6 társszerző is közremüködött. A Kerekasztal Konferencia feladata volt, hogy viták után összegezve egy szokásos színes poszterben az elfogadott javaslatok rövid összefoglalóját is közreadjuk. Ennek keretében a kockázatbesoroláson kívül még 11 táblázatban kellett megegyezni, amelyből készült posztert sok ezer magyar orvoshoz juttatjuk el. A Konszenzus Konferencia résztvevői a viták elősegítésére a 14 előadás absztraktját is megkapták, valamint a Promenade Kiadó honlapján az előadásokról és diákról készült videofilmek is megtekinthetők lesznek.

\section{Visszatekintés}

Hosszan lehetne sorolni, akárcsak a kockázatbesorolás vonatkozásaiként, hogy az első, 2003-as Konszenzus Konferencia (1) óta hogyan alakítottuk a kategóriákat, milyen táblázatokat állítottunk össze és forgalmaztunk, valamint hogyan jutottunk el 2017-ben a jelenlegi ajánlásokhoz, irányelvekhez. Ez azonban meghaladná írásunk terjedelmét, így ehelyütt csak a leglényegesebb változásokat követve és figyelembe véve tekintünk viszsza a kockázatbesorolást érintő témákra.

Igen jelentős volt, hogy az ATPIII 2004-ben először vetette fel - de csak még opcionálisan - a very high risk kategóriát, szigorítva $1,8 \mathrm{mmol} / \mathrm{l}$-es LDL-koleszterin (Ch) célértékkel. A magunk részéröl ezt az elsők között követtük és 2007-ben már nem opcionálisan, hanem fix kategóriaként vettük át. Változott a diabéteszrizikó szerepének a megítélése is. Kétszer is megjelöltük önálló rizikó ekvivalensként, máskor meg csak a kardiovaszkuláris betegség (CVD) kíséröjeként (CVD+diabétesz együttes jelenléte jelentette az igen nagy kockázatot).

A Magyar Kardiovaszkuláris Konszenzus Konferencia (MKKK) a veseelégtelenséget már 2007-ben bevezette súlyos rizikóként, míg az ESC/EAS csak 2011-ben.

2011-ben bevezettük az igen nagy kockázatba kiemelten az akut súlyos állapotokat (akut koronária szindróma, stroke, kritikus végtag-iszkémia), ahol a célértéktöl független statinkezelés, a legalább $50 \%$-os LDL-Ch-csökkentés elérése elvárható.

2009. és 2011. évben az MKKK a diabéteszt, vesebetegséget csak CHD-hoz kapcsolva vette be az igen nagy kockázatba, de 2014-ben már önállóan, ha bizonyos rizikót növelő paraméterekkel voltak súlyosbítva.

\section{Vitatott témák, határozatok}

A Magyar Kardiovaszkuláris Konszenzus Konferenciáknak (MKKK) mindig jelentős, sokszor a legföbb vitát kiváltó programja volt a Kockázatbesorolás kategória áttekintése. A VI. MKKK ajánlás előkészítésénél az ATP-ajánlásokat (2), az ESC/EAS 2011-es (3), és az amerikai Lipid Szövetség (NLA) 2014-es (4) ajánlásait vettük figyelembe, de jelenleg elsősorban az Európai Kardiológiai Társaság (ESC) és az Európai Atherosclerosis Társaság (EAS) 2016 augusztusában kiadott közös irányelveire (5) támaszkodhattunk. A 2013-as amerikai ACC/AHA (6) ajánlást is figyelemmel kísértük, noha az 3-4 dologban is (kockázatbesorolás, célérték,

\section{TÁBLÁZAT. VI. MKKK-2014. 1. Kockázatbesorolás}

\section{Kockázatbesorolás}

\section{Igen nagy kockázat}

- Akut súlyos állapotok: akut koronária szindróma, stroke, kritikus végtag-iszkémia

- *Klinikailag igazolt vagy invazív/nem invazív módszerrel dokumentált ateroszklerotikus koronária, cerebrális és perifériás érbetegség

- Súlyos krónikus vesebetegség (GFR $<30 \mathrm{ml} / \mathrm{min} / 1,73 \mathrm{~m}^{2}$ és proteinuria)

- Diabetes mellitus (1-es és 2-es típus) és $\geq 1$ nagy rizikófaktor (RF) és/vagy szervkárosodás

- Familiáris hypercholesterinaemia

- SCORE ${ }^{3} 10 \% / 10$ év

*Korábbi myocardialis infarctus, iszkémiás stroke, TIA, aorta aneurysma, koronária $(\mathrm{PCl}, \mathrm{CABG}) /$ carotis/perifériás revaszkularizácós beavatkozás; koronária angiográfia, UH, MR, $\mathrm{CT}$, stressz-echokardiográfia v. SPECT, carotis IMT, koronária calcium score

RF=Nagy kockázati tényezők: életkor, dohányzás, hipertónia, magas koleszterinszint.

\section{Nagy kockázat}

- Kardiovaszkuláris tünetek nélküli szubklinikus ateroszklerózis

- Nem invazív módszerrel kimutatott ateroszklerózis v. plakk (UH, MR, CT)

- Boka-kar index $\leq 0,9$

- Diabetes mellitus (1-es és 2-es típus) és 0-1 nagy rizikófaktor (RF)

- Krónikus vesebetegség (eGFR 30-60 ml/min/1,73 m² és/ vagy proteinuria)

- Familiaritás (korai CV-esemény, férfi $<55$, illetve nő $<65$ év)

- Egyes súlyos rizikófaktorok: (önállóan) - $R R>180 / 110$ Hgmm

- Atherogen dyslipidaemia, egyéb familiáris atherogen dyslipidaemiák

- Testtömegindex (BMI) $>40 \mathrm{~kg} / \mathrm{m}^{2}$

- Metabolikus szindróma

- SCORE 5\% - 10\%/10 év között

\section{Közepes kockázat}

$-\geq 2$ nagy rizikófaktor (RF)

- SCORE 1\% - 5\%/10 év között

\section{Kis kockázat}

- 0-1 nagy rizikófaktor (RF)

- SCORE $\leq 1,0 \% / 10$ év 
non-statinterápia, rizikókalkulátor) jelentősen különbözik az európaiaktól.

Egy ilyen új magyar irányelv megszerkesztésénél is elsősorban azt kell eldöntenünk, hogy változtassunk-e valamilyen mértékben az előző 2014-es ajánlásunkon (1. táblázat).

Ebből a szempontból a CV betegségek rizikóbesorolását, a diabéteszrizikó ekvivalenciájának kérdését, a mindinkább előtérbe kerülő vesebetegségeknek a nefrológusok által szorgalmazott számos, igen sokféle rizikóbeosztásának megítélését, a familiáris hypercholesterinaemia $(\mathrm{FH})$ helyének megtalálását kellett állásfoglalásokkal lezárni. Emellett jelentős feladatot és diszkussziót jelentett a nagy kockázat kategorizálása, ahol föleg az ESC/EAS irányelv alapján a 2014-es VI. MKKK-hoz (7) képest kellett új megközelítésekbe belemennünk.

\section{Vitatémák}

\section{Kardiovaszkuláris betegségek rizikóbesorolása}

2014-ben még bizonyos kockázati különbséget fenntartottunk a dokumentált és tüneteket okozó CV betegségek, valamint a szubklinikus ateroszklerózis között. Most azonban elérkeztünk oda, részben kardiológusaink véleményének és késztetéseinek hatására, meg az ESC/EAS irányelvek alapján, hogy egyszerübben fogalmazva minden érterületi dokumentált ateroszklerotikus CV betegséget az igen nagy kockázatba soroltunk. Így a CV tünetmentes betegségek, szubklinikus ateroszklerózis sem maradtak a nagy kockázatban. A poszter táblázatban részletesen is felsoroltuk és megneveztük a klinikai és szubklinikai $\mathrm{CV}$ betegségeket (megjegyezzük, hogy a vitában elhangzott még - de ezt nem nevesítettük -, hogy a carotis vonatkozásában a rizikót a szignifikáns plakk és nem az intima-media megvastagodás jelenti).

\section{Diabétesz}

2014-ben a diabéteszt akkor tartottuk igen nagy kockázatban, ha szervkárosodás (neuropathia, nephropathia, retinopathia) vagy a major rizikófaktorok valamelyike (életkor, hypercholesterinaemia, hipertónia, diabétesz) kísérte. A vitában azonban utalás hangzott el arra, hogy Haffner és munkatársai azt igazolták, hogy egy diabétesz jelenléte ugyanolyan nagy rizikó, mint egy lezajlott infarktus az anamnézisben.

Így felvetődhet, hogy a diabétesz önálló jelenléte is azonos értékü CHD rizikó ekvivalens, tehát szervkárosodás, vagy rizikófaktorok nélkül is behelyezhető lenne az igen nagy kockázatba. Az „Should All Diabetic Patients Be Treated With a Statin?" címü cikkben (8) több mint tucatnyi vizsgálatban dolgozták fel ezt a kérdést, amelynek összegzése szerint mintegy tucatnyi vizsgálatból fél tucatnál a CHD nagyobb rizikót jelentett, mint az önálló diabétesz, másik fél tucatnál pedig nem volt differencia. Ezek között a vizsgálatok között olyan híres és igen nagy létszámú vizsgálatok is szerepeltek, mint például a Nurses Health Study, a Physicians Health Study, az ARIC és a PROCAM Study, százezres és tízezres beteganyagokkal. Egyértelmú volt az állásfoglalás, hogy a fenyegetően terjedő, nagy veszélyeztetettségü diabétesz még mindig nem tekinthető CHD rizikó ekvivalensnek.

\section{Vesebetegségek}

2014-ben a krónikus vesebetegséget besoroltuk már az igen nagy kockázatba, azzal a megjegyzéssel, ha a GFR $<30 \mathrm{mml} / / 1,73 \mathrm{~m}^{2}$ és valamilyen mértékü proteinuria is jelen van. Az előkészítő Kerekasztal Konferencián és a konferenciai előadásukon is a nefrológusok számos érvet soroltak fel, miszerint nem egyszerüsíthető le a probléma az általánosan proteinuriának nevezett szövődményre, hanem azt fokozatokra kell osztani. A Metabolizmusban a nefrológusok által közölt cikkükben látható az az ábra, hogy proteinuria és a GFR számos fokozatát külön-külön meghatározó rizikó minőségbe sorolták be, például az ACR (vizeletalbumin/kreatinin hányados), vagy a TPCR (vizelet összfehérje/kreatinin hányados) alapján.

Az volt a többségi vélemény, hogy ez egy szűkszavú, a lényegre szorítkozó poszterbe beépítve nem lehetséges, nem követhető. Akik bele akarnak ebbe mélyedni, azok kvázi opcionálisan megtehetik, bár a háziorvosi praxisban ritka például az ACR-, TPCR-értékek mérése, kiszámítása, értelmezése.

Végül is a poszternél leegyszerúsítve abban maradtunk, hogy a <30-as GFR-érték és proteinuria fennállása esetén beszélhetünk igen nagy kockázatról.

\section{Familiáris hypercholesterinaemia (FH)}

Tekintettel a kezelés nélkül igen nagy kockázatra, a 40-50 éves korban szívinfarktus fenyegetettséget jelentő, minden 200-250. lakosban előforduló familiáris hypercholesterinaemiát (FH) (9) 2014-ben indokoltnak tartottuk ide sorolni. Ezen egyének Ch és LDL Ch szintje olyan magas a fokozott endogén Ch-szintézis és az egyidejüleg csökkent lebontás miatt, hogy diétával nem érhető el a célérték (Ch: 3,5, illetve LDL-Ch 1,8 mmol/l) megközelítése sem. Így mindannyian gyógyszeres kezelésre, optimálisan a pleiotróp hatást is biztosító statin és a felszívódást gátló ezetimib kombinált terápiájára, vagy újabban PCSK9-gátló kezelésre is szorulhatnak. Bár 2014-ben közösen elfogadtuk az FH igen nagy kockázatba helyezését, de kardiológusaink a 2016os ESC/EAS ajánlással ezt nem tartják konformnak és más külföldi ajánlásokban sem szerepel itt (kivétel lehetne, hogy az ACC/AHA statin benefit groupjaiban szerepel). A kardiológusaink szerint igen nagy kockázatba jelöléshez jó lenne valamilyen ateroszklerotikus képlethez kapcsolni, de végül is megegyeztünk, hogy legyen ez önállóan „opcionális”, fakultatív és perszonalizálva az orvos-beteg kapcsolatban történjen meg a 
döntés. Ez lényegében azt jelenti, hogy ha a nagy kockázatban a > $8 \mathrm{mmol} / \mathrm{l}$ koleszterinszint esetén a familiáris hypercholesterinaemia a Dutch Lipid Clinic Network pontrendszere esetén igazolható, akkor átkerülhet az igen nagy kockázatú csoportba (10).

\section{Egyes súlyos rizikófaktorok önálló beemelése a nagy kockázatba - SCORE?} Jelentős vitatéma volt, hogy a 2014-es kockázatbesorolásban az atherogen dyslipidaemiát, a $40 \mathrm{~kg} / \mathrm{m}^{2} \mathrm{fe}-$ letti BMI értékú elhízottakat, a metabolikus szindrómás betegeket, valamint olyan eseteket, amikor familiaritás van jelen (korai $C V$ esemény a családban, férfi< $<5$, illetve nő <65 év), a nagy kockázatba helyeztük, mivel úgy gondoltuk, hogy ezek rizikó jelentősége önmagukban megközelítheti a 4 major rizikófaktor jelentőségét, még ha az ESC/EAS ajánlásban ezek nem is kaptak kiemelt szerepet. Mi szerettük volna „kimenekíteni” ezeket a rizikófaktorokat a törlésből. Szollár professzor javaslata segített a megoldásban, amely a SCORE Chart kibővített értelmezésén alapult.

\section{SCORE Chart}

Elvi állásfoglalás, hogy a SCORE Chart-ot nem kell használni akkor, hogy ha igen nagy kockázatban vagyunk, annak a használata a primer prevencióban logikus. Mégis el lehet képzelni olyan primer prevenciós állapotokat, amikor a SCORE csak 4 nagy rizikófaktorból álló besorolása primer prevencióban is az igen nagy kockázati besorolással vetekszik. Ezért maradt bent az ajánlásokban a SCORE >10\%/10 éves fatális CVD-rizikó. A nagy kockázat már döntően a primer prevencióba tartozik, ha SCORE értéke $>5 \%$ és $<10 \% / 10$ év. A SCORE szempontjából közepes kockázatot mutat, ha a SCORE leegyszerüsítve minimum 2, maximum 4\% között van, míg kis kockázatban értéke $1 \%$, vagy 0.2014 -ben a közepes és kis kockázatot nemcsak a SCORE-ral, hanem a rizikófaktorok számával duplikátumként is jeleztük. Figyelembe véve azonban azt a kedvezőtlen tendenciát, hogy el kell ismerni, hogy a SCORE Chart sajnos a kívánatosnál sokkal kevésbé terjedt el, jobb lenne, ha a gyakorló orvosokat afelé terelnénk, hogy ne a rizikófaktorokkal, hanem a SCORE-ral mérjék a nagy, a közepes és kis rizikót. Nagy kockázatban az egyes súlyos kockázati tényezők közül a >180/110 Hgmm vérnyomás, a >8 mmol/l összkoleszterinszint, a boka-kar index $>0,9$ értéke maradt meg. Itt kapott helyett minden cukorbeteg, aki nem tartozik az igen nagy kockázatú csoportba, de nem sorolandók ide a fiatal 1-es típusú cukorbetegek. A nagy kockázatba tartozik még a krónikus vesebetegség 30-60 közötti GFR-rel és/ vagy proteinuriával.

\section{A SCORE értelmezésének kibővítése}

Ahogy utaltunk rá, a SCORE értelmezésének kibővítését is figyelembe kell venni, ahogy az az ESC/EAS irányelvekben, táblázatban is szerepel (2. táblázat) a
2. TÁBLÁZAT. SCORE CHART kiegészítő rizikófaktorai

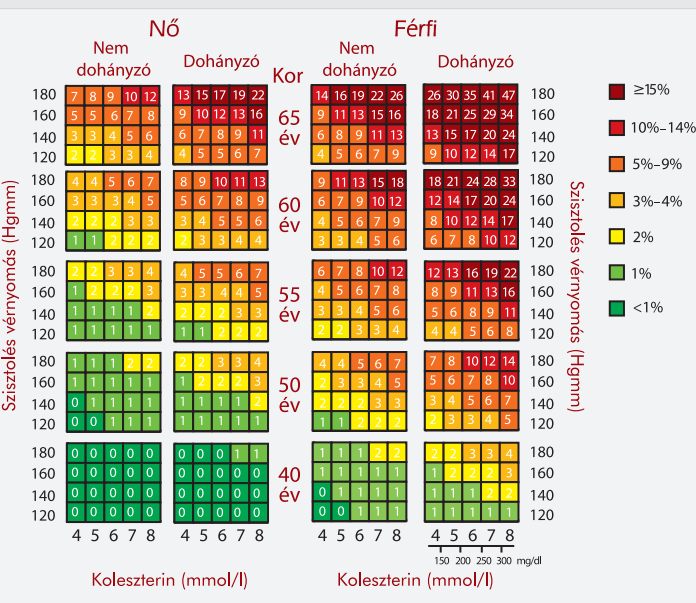

A SCORE kockázatbecslés által meghatározott esély (kis, közepes, és néha nagy kockázat esetén is) nagyobb lehet (egy osztállyal feljebb sorolható) az alábbiak jelenlétében:

- Erős családi halmozódású és/vagy korai fellépésű (férfiak: $<55$ év; nők: <65 év alatt) kardiovaszkuláris betegségek.

- Mozgásszegény (ülő) életmód.

- Centrális (android) elhízás, nagy BMI

(pl. BMI > $40 \mathrm{~kg} / \mathrm{m}^{2}$ felett $40 \times$ nagyobb a hirtelen szívhalál esélye) és nagy haskörfogat.

- Metabolikus szindróma, atherogen dyslipidaemia (magas triglicerid és alacsony HDL-koleszterin érték).

- Hátrányos társadalmi-gazdasági helyzet, elszigetelődés továbbá a támogatás hiánya (például néhány országban a nagyszámú etnikai kisebbség esetében).

\section{TÁBLÁZAT. VII. MKKK-2017. 1. Kockázatbesorolás}

\section{Kockázatbesorolás}

\section{Igen nagy kockázat}

- Akut súlyos állapotok: akut koronária szindróma, stroke, kritikus végtagiszkémia.

- Klinikailag igazolt vagy képalkotó eljárással dokumentált ateroszklerotikus koronária, cerebrális, perifériás verőérbetegség: - korábbi miokardiális infarktus, iszkémiás stroke, TIA, aorta aneurysma, claudicatio intermittens, koronária ( $\mathrm{PCl},-$ CABG)/carotis/perifériás revaszkularizációs beavatkozás, nem traumás végtag-amputáció

- Képalkotók: koronária angiográfia, UH, MR, CT.

- Diabetes mellitus (1-es és 2-es típus) és célszervkárosodás (pl. proteinuria) vagy jelentős lipidemelkedéssel vagy jelentős vérnyomás-emelkedéssel, vagy dohányzással társult cukorbetegség.

- Súlyos krónikus vesebetegség (GFR <30 ml/min/1,73 m² és proteinuria).

- Familiáris hypercholesterinaemia (opcionális SCORE $\geq 10 \%$ / 10 év.

Nagy kockázat

- Egyes súlyos kockázati tényezők (önállóan): vérnyomás $>180 / 110$ Hgmm, koleszterinszint $>8,0 \mathrm{mmol} / \mathrm{l}$.

- Diabetes mellitus: minden cukorbeteg, aki nem tartozik az igen nagy kockázatú csoportba, de nem sorolandók ide a fiatal, 1-es típusú cukorbetegek.

- Krónikus vesebetegség (GFR 30-60 ml/min/1,73 m² és/vagy proteinuria)

- Boka-kar index $\leq 0,9$.

- SCORE $\geq 5 \%$ - $<10 \% / 10$ év.

$\begin{array}{ll}\text { Közepes kockázat } & \text { Kis kockázat } \\ - \text { SCORE }>1-<5 \% / 10 \text { év. } & - \text { SCORE } \leq 1,0 \% / 10 \text { év. }\end{array}$


SCORE Chart mellékleteként felsorolnak néhány olyan rizikófaktort, amely jelenléte kockázatnövelő tényező. Ebben benne van az atherogen dyslipidaemia, a familiaritás, a kóros elhízás és javasoltuk, hogy a Konszenzus Konferencián evidence based adatokkal igazolt krónikus gyulladásos betegségek - rheumatoid arthritis - is pluszban idesorolhatók. Fel kell készülnünk arra is, hogy az irányelveink nem örökéletűek, legújabban már az amerikai endokrinológiai társaságok kiadott új ajánlásai (2017) a very high risk fölé egy extrém rizikókategóriát is kialakítottak.

Miután a kockázatbesorolás a Konszenzus Konferencia szinte minden komponensére kihat és annak az alapjának is tekinthető, megelégedéssel tölthet el bennünket - minden közreműködőnek köszönettel - hogy egységes álláspontot sikerült kialakítanunk (3. táblázat), segítséget adva a mindennapos orvosi tevékenységhez.

\section{Irodalom}

1. Magyar Terápiás Konszenzus Konferencia. Budapest; 2013. november

2. Grundy SM, Cleeman JI, Merz C, et al. Implications of recent clinical trials for the National Cholesterol Education Program Adult Treatment Panel III Guidelines. Circulation 2004; 110: 227-239. doi: 10.1161/01.CIR.0000133317.49796.0E

3. Reiner Z, Catapano AL, Guy De Backer, et al. ESC/EAS Guide- lines for the management of dyslipidaemias. The Task Force for the management of dyslipidaemias of the European Society of Cardiology (ESC) and the European Atherosclerosis Society (EAS). Atherosclerosis 2011; 217: 3-46. doi: 10.1093/eurheartj/ehr158

4. Jacobson TA, Ito MK, Maki KC, et al. National Lipid Association recommendations for patient-centered management of dyslipidemia. $J$ Clin Lipidol. 2014; 8: 473-488. doi: 10.1016/j.jacl.2015.02.003

5. Catapano AL, Graham I, Guy De Backer, et al. 2016 ESC/EAS Guidelines for the Management of Dyslipidaemias. Eur Heart J 2016; 37: 2999-3058. doi: 10.1093/eurheartj/ehw272

6. Stone NJ, Robinson JG, Lichtenstein AH, et al. 2013 ACC/AHA Guideline on the treatment of blood cholesterol to reduce atherosclerotic cardiovascular risk in adults. Circulation 2014; 129: S1-S45. doi: 10.1016/j.jacc.2013.11.002

7. Pados Gy, Karádi I, Kiss RG, Paragh Gy, Szollár L. Kardiovaszkuláris kockázatbesorolás 2014. Metabolizmus 2015; 13(1): 4-7.

8. Kamari Y, Bitzur R, Cohen H, et al. Should all diabetic patiens be treated with a statin? Diabetes Care 2009; 32(Suppl 2): S378-S383. doi: $10.2337 / \mathrm{dc} 09-\mathrm{S} 344$

9. Nordestgraad BG, Chapman HJ, Humphries SE, et al. Familial hypercholesterinaemia is underdiagnosed and undertreated in the general population: guidance for clinicians to prevent coronary heart disease. Eur Heart J 2013; 34: 3478-3490. doi: 10.1093/eurheartj/ eht273

10. Piepoli MF, Hoes AW, Ageall A, et al. 2016 European Guidelines on cardiovascular disease prevention in clinical practice. Atherosclerosis 2016; 252: 207-274. doi: 10.1093/eurheartj/ehw106

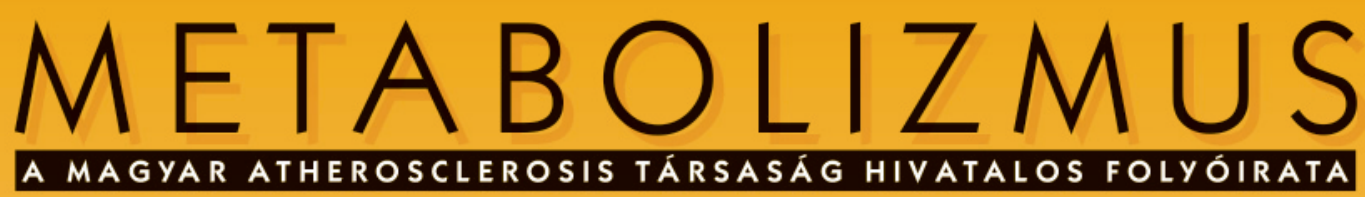

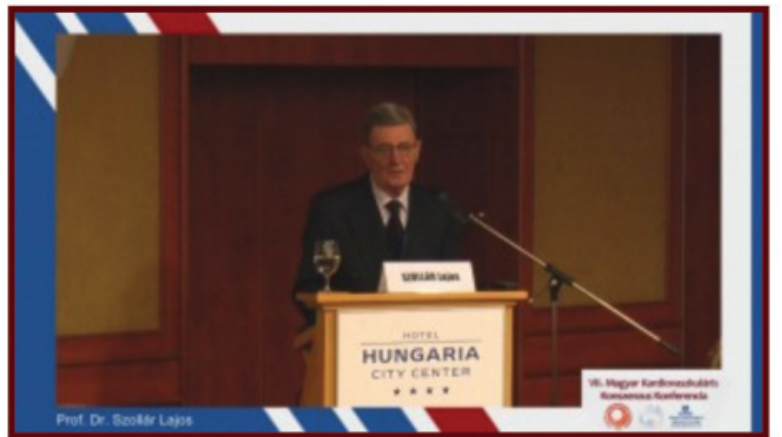

\section{A kardiovaszkuláris kockázatbesorolás szempontjai}

Egy beteg kezelése során első lépés kell, hogy legyen a beteg kockázati tényezőinek a felmérése, hiszen ez számos terápiával kapcsolatos döntést alapvetően befolyásol. A VII.

\section{Gondolatok az érdemi munka előtt}

A VII. Magyar Kardiovaszkuláris Konszenzus Konferenciára 2017. december 1-én került sor, amelyet a konferencia elnökeként Szollár Lajos professzor nyitott meg. Mint mondta: "A ma tudománya a holnap tévedése", ami indokolttá teszi, hogy a 17 orvosszakmai társaság együttmüködésével zajló tudományos ülésen áttekintve az elmúlt három esztendő új vizsgálati eredményeit, megújitsák a mindennapi terápiás gyakorlat számára szolgáló ajánlást.

\section{Kardiovaszkuláris kockázat hazánkban és Európában}

\footnotetext{
A legfrissebb adatok is azt a szomorú képet erősítik meg, hogy a kardiovaszkuláris mortalitás terén hazánk elmaradása a fejlett európai országoktól inkább növekvő
}

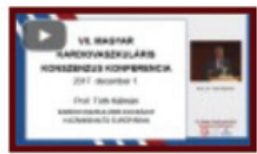

A VII. Magyar Kardiovaszkuláris Konszenzus Konferencia elốadásai online is elérhetô: http://metabolizmusonline.hu/rovatok/kardiovaszkularis-konszenzus-konferencia-2017 